\title{
The implementation of teaching model to induce simson tarigan's concept change (m3pk) to improve student chemistry learning outcomes in the subject of reaction equation class $\mathrm{x}$ man binjai
}

\author{
Dwy Puspita Sari ${ }^{1,2 *}$, Marini Damanik ${ }^{2}$, Simson Tarigan ${ }^{2}$ \\ 'Chemistry teacher, Sekolah Menengah Atas Negeri l, Langkat, Indonesia \\ ${ }^{2}$ Department of Chemistry, Universitas Negeri Medan, Medan 20221, Indonesia
}

\begin{abstract}
:
This study aims to determine the improvement of students' chemistry learning outcomes by applying M3PK. The population were all students of class X MIA. The sample consisted of two classes, namely class $\mathrm{X} M \mathrm{MIA} 2$ and $\mathrm{X}$ MIA 3 which were taken by random sampling. The first class is used as an experimental class which is taught using the Teaching Model to Induce Change of Concepts, and the second class as a control class which was learnt by using the Direct Instruction. As a prerequisite for testing the hypothesis, the study data of the two sample groups were tested for normality and homogeneity and the data achieved from both sample groups were normal and homogeneous. In testing, the hypothesis obtained the price of $t_{\text {count }}>t_{\text {table }}(4.619>1.670)$. It shows that the alternative hypothesis $(\mathrm{Ha})$ is accepted and the null hypothesis $(\mathrm{Ho})$ is rejected, which means that the increase in learning outcomes of chemistry students who are learnt by using M3PK is higher than the learning outcomes of chemistry students who are educated using the Direct Instruction. The percentage increased in students' learning outcomes of chemistry learnt by using M3PK was $74.5 \%$ while those taught using the Model Direct Instructionwere $64.8 \%$.
\end{abstract}

Keywords:

equation reactions; $\mathrm{m} 3 \mathrm{pk}$; learning outcomes

\section{Introduction}

Education has an important role in shaping the personality and abilities of a nation and the world community. Education is a conscious and planned effort for the realization of a learning atmosphere and learning process so that students actively develop their potential to have religious spiritual strength, self-control, intelligence personality, noble character, and skills needed by themselves, society, nation and state (Fajariah et al. 2016).

However, the learning activities that are often encountered teachers are still being the center of learning (teacher centered learning). Learning activities should be held student-centered learning. In addition, the learning approach should used the contextual, no longer textual. Learning is not just learning concepts, theories, and facts but also studying the application of

\footnotetext{
* Corresponding author.

dwypuspita.sari@yahoo.co.id

doi: https://doi.org/10.2 4114/jpkim.v10i3.12719
}

knowledge acquired in everyday life. However, in the field, there are still many students who memorize the concept. There are less able to use the concept if they encounter problems in daily life related to the concepts they have. This can affect student learning achievement (Anggraini et al. 2012; Silaban \& Simangunsong, 2015; Retnasari et al. 2016).

Chemistry is one of the science lessons that applies to the high school curriculum. These chemical subjects are subjects that require memorization, calculation and concepts. Compound Nomenclature and Reaction Equation is one chemical subject in class X Semester 11 . These subjects require the application of concepts and memorization so that students need concentration and attention in following these subjects. As a result, if the teacher does not provide material presentation and learning processes that are in accordance with the subjects of compound names and reaction equations will cause students to get bored quickly and not interested in understanding the concepts in the 

reaction equation class $x$ man binjai

material so that their learning achievement becomes low (Islamic et al. 2016; Silaban, 2017).

Therefore, it needs a learning model that can overcome the above problems. And one alternative is $M 3 P K$. According to some previous studies that $\mathrm{M} 3 \mathrm{PK}$ learning techniques are superior in improving results compared to individual or competitive learning experiences.

\section{Materials and Methods}

This study was conducted at MAN Binjai Pakan Baru Street in the even semester of the 2016/2017 Academic Year. The population in this study was all students of class X MIA who used the 2013 curriculum. Students of class $X$ MIA in MAN Binjai with 4 classes. Each class has an average of 40 students.

The sample in this study consisted of two classes namely class X MIA 2 and X MIA 3 which were taken randomly. The first class was used as the experimental class which was taught using M3PK, and the second class was used as the control class that was taught using Direct Instruction Model. Based on the problems studied and the objectives of the study, this type of research is an experimental study using the Pretest-Postest Group Design model which is showed on Table 1 . In this study the research instrument used was a test instrument to measure cognitive learning outcomes (pretest and posttest).

Table 1

Research design

\begin{tabular}{lrcc}
\hline Group & $\begin{array}{c}\text { Pre- } \\
\text { test }\end{array}$ & Treatment & Post-test \\
\hline Experimental 1 & $\mathrm{T}_{1}$ & $\mathrm{X}_{1}$ & $\mathrm{~T}_{2}$ \\
Experimental 2 & $\mathrm{T}_{2}$ & $\mathrm{Y}_{1}$ & $\mathrm{~T}_{2}$ \\
\hline
\end{tabular}

The test form of students' chemistry learning outcomes is multiple choice questions, which are arranged with five answer choices namely a, b, c, $\mathrm{d}$ and e. The test items are designed to cover four cognitive regions according to Bloom's Taxonomy, namely aspects of knowledge $(\mathrm{Cl})$, understanding (C2), application (C3) and analysis (C4). The number of questions used for the study were 40 items. But beforehand, the questions were validated and tested first.

Before conducting an evaluation, the tests will be standardized using standard procedures for standardizing tests, questions in the evaluation test will be validity, reliability, differentiation and level of difficulty using statistics, then the number of questions used is a number of valid questions.
In this study the data processed is the learning outcomes of students of both classes. The data analysis technique used is analysis using the t-test formula. Before carrying out the t-test, the following steps are carried out first: Determining Average Values and Standard Deviation, Normality Test, Data Homogeneity Test, Learning Outcomes Improvement Test (\%).

\section{Results}

\section{Description of research results}

Based on the results of the research conducted, data obtained are presented in Table 2. Based on the average score table of the learning outcomes above, a graph can be presented below. The posttest average score in the higher experimental class is compared with the posttest average score in the control class (Fig 1).

\section{Table 2}

Research data

\begin{tabular}{lcc}
\hline \multirow{2}{*}{ Group } & \multicolumn{2}{c}{ Score Average Learning Outcomes } \\
\cline { 2 - 3 } Experiment & Pre-Test & Post-Test \\
\cline { 2 - 3 } Control & 6,424 & 16,576 \\
\hline
\end{tabular}

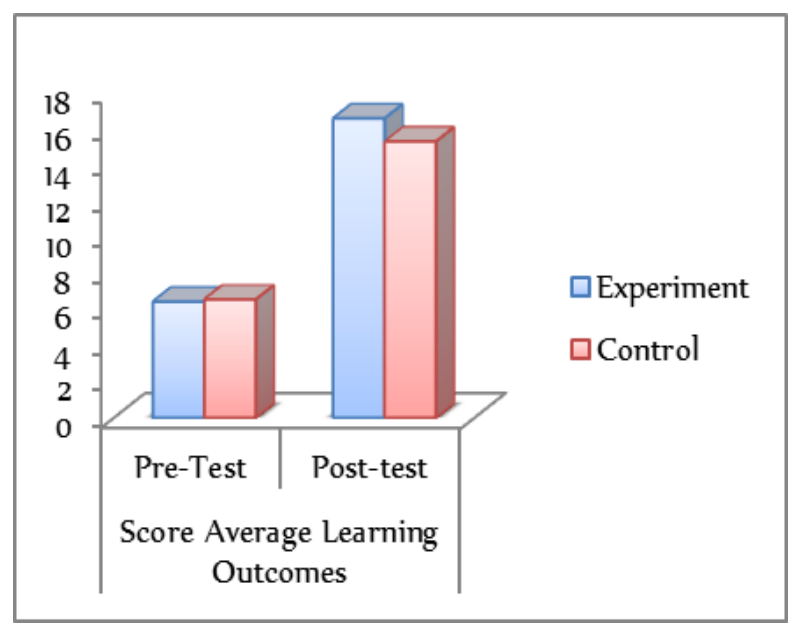

Figure 1. Score of average learning outcomes

The normality test uses the Chi Square test at the significance level $\alpha=0.05$ with $\mathrm{db}=5$. With the Chi Squared criterion $\left(\chi^{2}\right)_{\text {count }}<\left(\chi^{2}\right)_{\text {table }}$. Based on the results of the Chi Square test calculation for the experimental class pretest obtained $\left(\chi^{2}\right)_{\text {count }}=4.912$ while $\left(\chi^{2}\right)$ the table at $\alpha$ $=0.05 \mathrm{db}=5$ is 11.07. Then obtained $\left(\chi^{2}\right)_{\text {count }}<$ $\left(\chi^{2}\right)_{\text {table }}(4.912<11.07)$, so that the pretest data is normally distributed. 


\section{Hypothesis testing}

After it is known that the data is normally distributed and homogeneous, hypothesis testing can be carried out using the t-test statistical test (right-party test). This test is used to determine whether the hypothesis in this study is accepted or rejected. Test criteria if $t_{\text {count }}>t_{\text {table }}$ then the alternative hypothesis ( $\mathrm{Ha}$ ) is accepted and the null hypothesis $(\mathrm{Ho})$ is rejected. For the value of $t$ count, consult at $t_{\text {table (0.05) (64), but the value of } t_{\text {table }}}$ is not found in table $t$, then the value of $t_{\text {table }}$ can be obtained by interpolation. Based on the results of the calculation of learning outcomes test, the price of $t_{\text {count }}>t$ table is 4,619>1,670 with a significance level of $\alpha=0.05$ so $\mathrm{Ha}$ is accepted which means the Teaching-lnducing Change Concept Model can improve student chemistry learning outcomes.

\section{Percentage of increased learning outcomes}

Learning success is characterized by an increase in student learning outcomes. Calculation of the percentage increase in student learning outcomes is done by the gain formula. The percentage of students' increased chemistry learning outcomes in the experimental class is higher, with an increase of $74.5 \%$ while in the control class an increase of $64.8 \%$. Increased chemistry learning outcomes of students in the experiment with a high category while in the control class with a moderate category which is showed in Table 3 and Fig 2.

Table 3 .

Data on improving learning outcomes (gain)

\begin{tabular}{clll}
\hline Group & \multicolumn{1}{c}{ Criteria } & $\%$ Gain & Criteria \\
\hline Experiment & $\mathrm{g}<0,3=$ low & $75 \%$ & high \\
& $\begin{array}{l}0,3 \leq \mathrm{g} \leq 0,7= \\
\text { moderate } \\
\text { Control }\end{array}$ & $64,8 \%$ & moderate \\
& $\mathrm{g}>0,7=$ high & & \\
\hline
\end{tabular}

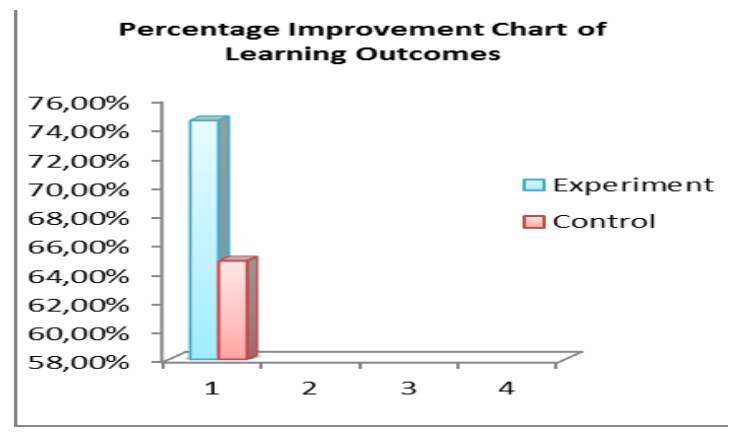

Fig 2. Percentage chart for improving learning outcomes
From the results of data analysis, it was found that the average chemistry score of students on the subject matter of Compound Names and Reaction Equations in the experimental class using the Teachers-Inducing Change Concept (M3PK) model was higher $(X=16,576)$ compared to the control class $(X=15,303)$.

\section{Discussion}

In many cases, conceptual change which is a restructuring of the learner's prior to knowledge. It is a necessary part of acquiring new conceptual knowledge (Carey, 1985; Posner et al. 1982; Clement \& Vosniadou, 2008). We expected conceptual change which still be relevant in higher education. Learning by conceptual change has been described as a general human learning mechanism that is relevant independently of age group and content domain. There are some similarities between children's thinking processes when acquiring new concepts and scientists' thinking processes. It develops a new theory, which hints at an age-general importance of conceptual change (Basili \& Sanford, 1991; Gentner et al. 1997, Flaig et al. 2018).

M3PK is a learning model that aims to induce correct concepts and structures to students. M3PK is a constructivist learning model. Students are guided to build their own understanding or students become learning centers. In this model, the concept changes are emphasized in the three aspects of the first, namely intelligibility, which means that the concept has meaning in students. The second aspect is plausible which means students are sure that the concept they received is correct. While, the third aspect is fruitfull which means that the concept provides fruit for him (Tarigan, 2012).

The discussion from the data analysis can be seen from hypothesis testing. From the hypothesis testing, it was found that $t_{\text {count }}=4.619$ and $t_{\text {table }}=$ 1.670 , then $t_{\text {count }}>t_{\text {table }}$ at $\alpha=0.05$, which indicates that $\mathrm{Ho}$ is rejected and $\mathrm{Ha}$ is accepted. This means that the M3PK model can improve student learning outcomes compared to student chemistry learning outcomes taught with the Direct Instruction Model on the subject of Class $X$ Reaction Equations in Binjai MAN 2016/2017 Academic Year. The results of data analysis obtained the average score of the experimental class (pretest $=6.424$, posttest $=16.576$, gain $=$ 0.745) with a percent increase in learning outcomes $74.5 \%$ while the average score of the control class (pretest $=6.576$, posttest $=15.303$, gain $=0.648$ ) with a percent increase in learning 

reaction equation class $x$ man binjai

outcomes $64.8 \%$. Increasing students 'chemistry learning outcomes taught with the M3PK model is higher than the students' chemistry learning outcomes taught with the Direct Learning Model, where the difference in increase is $9.7 \%$.

\section{Conclusion}

Based on the results of research and data processing, the researcher draws the following conclusions: M3PK can improve students' chemistry learning outcomes compared to student chemistry learning outcomes which are taught by Direct Instruction Model. With an average increase in learning outcomes with M3PK obtained at $74.5 \%$ and the average increase in learning outcomes with Direct Learning Model obtained by $64.8 \%$.

\section{References}

Anggraini, W., Ariani, S.R.D., \& Sukardjo, J.S (2012). Pengaruh pembelajaran kimia dengan pendekatan ctl (contextual teaching learning) melalui metode eksperimen dan proyek terhadap prestasi belajar ditinjai dari minat berwirausaha siswa pada materi destilasi kelas $x$ smk negeri 2 sukoharjo tahun ajaran 2011/2012. Jurnal Pendidikan Kimia, 1(1), 80-85.

Basili, P.A., \& Sanford, J.P. (1991). Conceptual change strategies and cooperative group work in chemistry. Journal of Research in Science Teaching, 28(4), 293-304.

Carey, S. (1985). Conceptual changes in childhood. MIT Press, MA, Cambridge.

Clement, J., \& Vosniadou, S. (2008). The role of explanatory models in teaching for conceptual change. International handbook of research on conceptual change, 1, 417-452.

Fajariah, N., Utami, B., \& Haryono. (2016). Penerapan model pembelajaran inquiry terbimbing untuk meningkatkan kemampuan berpikir kritis dan prestasi belajar pada materi kelarutan dan hasil kali kelarutan siswa kelas xi sma al-islam 1 surakarta tahun ajaran 2014/2015. Jurnal Pendidikan Kimia, 5(2), 8994.

Flaig, M., Simonsmeier, B. A., Mayer, A. K., Rosman, T., Gorges, J., \& Schneider, M. (2018). Conceptual change and knowledge integration as learning processes in higher education: A latent transition analysis. Learning and Individual Differences, 62, 49-61.

Gentner, D., Brem, S., Ferguson, R. W., Markman, A. B., Levidow, B. B., Wolff, P., \& Forbus, K. D. (1997). Analogical reasoning and conceptual change: A case study of Johannes Kepler. Journal of the Learning Sciences, 6(1).

Islamic, A.R., Sukardjo, J.S., \& Nurhayati, N.D. (2016). Penerapan metode pembelajaran team assisted individualization (tai) dilengkapi media handout untuk peningkatan prestasi belajar dan interaksi sosial siswa paa materi pokok tata nama senyawa kimia dan persamaan reaksi kimia kelas x sma negeri gondangrejo karang anyar tahun pelajaran 2013/2014. Jurnal Pendidikan Kimia, 5(2), 69-75.

Posner, G.J., Strike, K.A., Hewson, P.W., \& Gertzog, W.A. (1982). Accommodation of a scientific conception: Toward a theory of conceptual change. Science education, 66(2), 211-227.

Retnasari, R., Maulana, M., \& Julia, J. (2016). Pengaruh pendekatan kontekstual terhadap kemampuan koneksi matematis dan motivasi belajar siswa sekolah dasar kelas iv pada materi bilangan bulat. Jurnal Pena Ilmiah, 1(1), 391-400.

Silaban, S., \& Simangunsong, N.S.D. (2015). Pengaruh model pembelajaran contextual teaching and learning (ctl) terhadap hasil belajar siswa pada pokok bahasan sistem koloid. Jurnal Pendidikan Kimia, 7(01), 95-101.

Silaban, S. (2017). Dasar-dasar pedidikan matematika dan ilmu pengetahuan alam. Medan: Harapan Cerdas Publisher.

Tarigan, S. (2012). Pengantar Metode Penelitian Ilmiah, Unimed, Medan. 